\title{
Seasonal changes in the number of Relict Gull (Larus relictus) at Ebinur Lake, Western China
}

\author{
Ming $\mathrm{MA}^{1 *}$, Ying $\mathrm{CHEN}^{1}$, Kedeerhan BAYAHEN ${ }^{2}$, BaoWen $\mathrm{HU}^{1}$, Fei $\mathrm{LI}^{2}$, JiaQing $\mathrm{WU}^{2}$, Xiang $\mathrm{GAO}^{2}$, \\ Yu MEl ${ }^{1}$ \\ ${ }^{1}$ Key Laboratory of Biogeography and Bioresources in Arid Land, Xinjiang Institute of Ecology and Geography, Chinese \\ Academy of Sciences, Urumqi 830011, China; \\ ${ }^{2}$ Administrative Bureau of the National Nature Reserve in the Ebinur Wetland, Bole 833400, China
}

\begin{abstract}
The Relict Gull (Larus relictus) is recognized as a vulnerable species, with a worldwide population of about 6,000 individuals. Always inhabiting the extreme arid regions of Central Asia, their migratory routes and winter grounds are unclear. This research focused on distribution sites, habitat, behavior, population size and seasonal changes of Relict Gull. Line transects and point counts in every month were used to investigate the gulls around the Ebinur Lake. The result showed Relict Gull was summer visitor to Xinjiang, Western China. Population curve with a single peak was obtained. This gull appeared in early April and was 63 individuals ( $1 \%$ of the global population). The number remained stable from May to July in 2009. The discovery of fledglings indicates that Relict Gull may breed here. They left Ebinur Lake in August. Relict Gull in Ebinur Lake should belong to the Central Asian subpopulation, which was the most westerly record in China.
\end{abstract}

Keywords: Relict Gull (Larus relictus); population; seasonal change; Ebinur Lake; Central Asia

\section{Introduction}

Relict Gull (Larus relictus), just as its name implied, is a rare and relict species with breeding grounds floating and scattering in salt marshes of Asia. And it is one of the least known birds (Fig.1). Debates had arisen since the first sample was collected in Inner Mongolia in 1929 (Lönnberg, 1931), and it was regarded as a separate species until 1971 (Auezov, 1971). Their breeding grounds in China were Ordos Highland, Ruoshui in Alxa, and Wuliangsuhai in Inner Mongolia. The Ordos

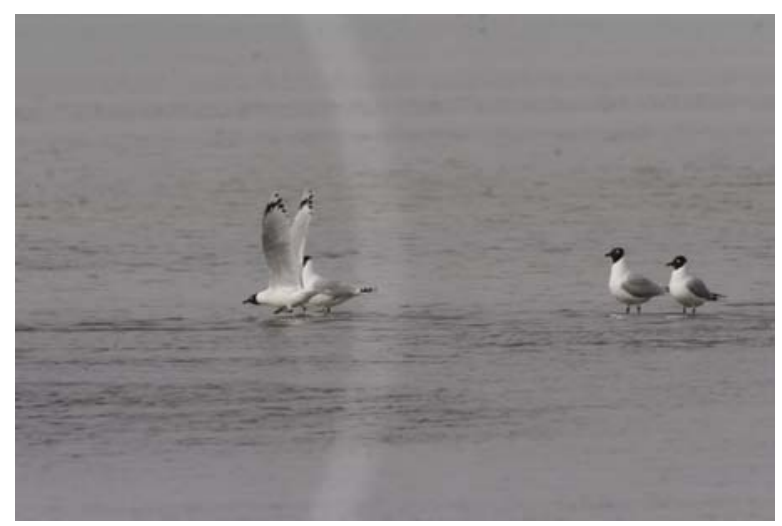

Fig. 1 Relict Gull in Ebinur Lake colony migrates through the provinces of Shaanxi, Inner Mongolia, Shanxi, Jiangsu, Hebei and along the Bohai coastline. Other three subpopulations are located in the Alakol Lake and Balchas Lake in Kazakhstan, Tatsain Tsagaan Nuur in Mongolia, and the Torey Lake in the Chita Region of Eastern Russia.

Recorded sites of the Relict Gull in Xinjiang were Alataw Pass, Ebinur Lake (including Bortala River and Jinghe River), small lakes near Karamay and Shihezi, Altay and Keksu Wetlands, Aksu and the upper reaches of the Tarim River, Yarkant River, Kizilsu and Kashi (Ma et al., 1997; Ma, 1999, 2001; He, et al., 2002; Wang et al., 2006; Yan et al., 2006). Because of the unstable population of Reilict Gull during the past 40 years, it was difficult to check their definite distribution sites. Therefore, population size, migratory routes or winter grounds were poorly known. We searched for the gull in Ebinur Lake in northern Xinjiang, and obtained some traces and data of the gull from May to October in 2008, and from April to October in 2009.

Received 2010-01-27, accepted 2010-03-31 doi: 10.3724/SP.J.1227.2010.00151

*Corresponding author: Ming MA (E-mail: maming@ms.xjb.ac.cn) 


\section{Study areas}

With the lowest altitude in Northern Xinjiang $\left(44^{\circ} 50^{\prime} \mathrm{N}, 82^{\circ} 50^{\prime} \mathrm{E}, 189 \mathrm{~m}\right.$ above sea level), the Ebinur Lake on the southwestern edge of Junggar Basin is an inland drainage terminus with a catchment area of $50,621 \mathrm{~km}^{2}$, In the early 1950 s about 23 rivers including Bortala, Jinghe, Sikeshu, Tuotuo and Kuytun discharged into the lake, and produced a lake with a surface area of up to $1,200 \mathrm{~km}^{2}$. Many rivers had been blocked because of human disturbance. Now, the Bortala and Jinghe Rivers replenish the lake. The area of Ebinur Lake fluctuated between $499 \mathrm{~km}^{2}$ and 1,200 $\mathrm{km}^{2}$ with the depth from $1 \mathrm{~m}$ to $2 \mathrm{~m}$.

Mean annual precipitation is $91 \mathrm{~mm}$ in Ebinur Lake area, whileas mean annual evaporation is $1,589 \mathrm{~mm}$. The annual average temperature is $5.6^{\circ} \mathrm{C}$. The Alataw Pass in the northwest of the basin is famous for gales with wind force above Beaufort Scale 8 for 165 days every year. The highest windspeeds was up to $55 \mathrm{~m} / \mathrm{s}$ between April and June. The Ebinur Lake located in the desert belt of Central Asia. Gravel and gypsum soils predominate in north of the Tianshan Mountains and the vegetation are Haloxylon spp. and Ephedra sinic. The eastern part of the basin is saline soils with Reaumuria soongorica. The central part of the basin is semi-fixed desert vegetated with Haloxylon spp. Succulent halophytes are abundant on the lake shores, such as Halocnemum strobilaceum, Salicornia europaea, Halostachys caspica as well as Tamarix spp. Along the river are Populus euphratica forest, reed marsh and lowland meadow. The lake is salty $(\mathrm{pH}$ 8.4-8.9; salinity up to $132 \mathrm{~g} / \mathrm{L}$ ) and the surrounding land is heavily mineralized. Gale and salt dust endanger birds. But abundant Brine Shrimp (Artemia spp.) and maggots of Ephydra spp. were found near the lake, which could provide rich food for some bird species.

\section{Methods}

Line Transect and Point Count were used to investigate the biology and ecology of Relict Gull. Binoculars $(10 \times 42)$ and telescopes (Teleye- $80 \mathrm{~A}, 40 \times)$ were used to observe bird locations, time, date, habitat, population size, outlines, age (adult or young), flight orientation and height, settling-in areas, feeding areas, and bird habits. The latitudes, longitudes and altitudes of the spots where we observed Relict Gull were recorded by GPS, and marked on the map (Fig. 2). For some suspect individuals and large populations, digital camera, video and audiotape were used to aid individual identification and population counts.

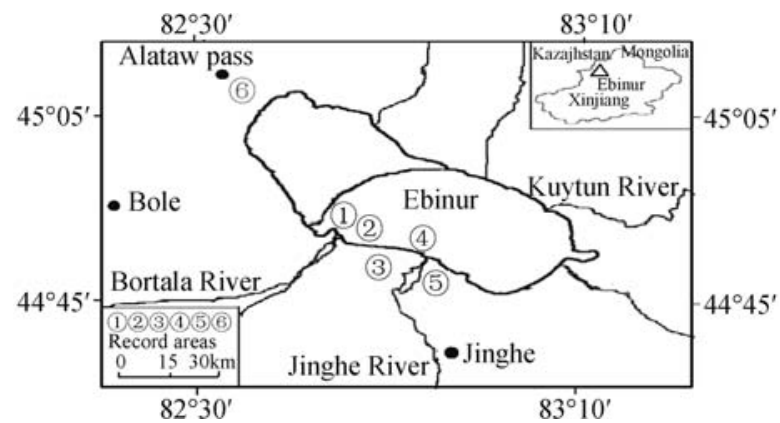

Fig. 2 Record areas of Relict Gull in Ebinur Lake (1)Estuary of Bortala River; (2)Silver Shoal; (3)Crab Pond; (4)Estuary of Jinghe River; (5)Aquaculture Farm; (6)Bazihu Lake, Alataw)

Survey spots around the lake were marshy near estuaries of the Jinghe and Bortala Rivers, and Alataw Pass (Fig. 2), and Bazihu Lake, Kekbarstaw, Sunderkum, the lower reaches of Kuytun River, Suyuek, Ganjiahu Nature Reserve, Yanchi Bridge, Duck Bay, Kuoketala, East Bridge, Daxinan, Caving Bridge, Guertu, Kezijiar lake, salt flat of the Jinghe River, a Crab Farm, Bayantala, Bird-watching Hide, Sumluk wetland, Silver Shoal in Ebinur Lake, Mogutan, and field station on Bird Islet. The survey region was 118 $\mathrm{km}$ long and $56 \mathrm{~km}$ wide, and total area was above $6.61 \times 10^{3} \mathrm{~km}^{2}$. Regular observations were used in 20 field stations in the national reserve around Ebinur Lake. The Excel 2003 and SAS 9.0 software were used for data analyses.

\section{Results}

The results showed that Relict Gull gathered in pairs or flocks around the estuaries with fresh water, where the environment was barren land. The birds were observed at estuaries, crab farm, shoal, meadow, desert, and pond near the town (Table 1). The behaviors of the bird, such as, flight, call, pairing, grouping, bathing, drinking, chasing, nodding, flirtation, copulation, searching for food, attacking and plumage were recorded. During the breeding season (April to June) all detected gulls were adults and seemed to have little fear of humans. We could approach them to within a distance of 20-30 m. Most of gulls were in pairs or small groups; they were scarcely alone and did not mix with other waterfowl. 
Table 1 Six populations of the Relict Gull in Ebinur Lake during the period 2008-2009

\begin{tabular}{|c|c|c|c|c|c|c|c|c|c|}
\hline \multirow{2}{*}{ Sites } & \multirow{2}{*}{ Position } & \multicolumn{2}{|c|}{2008} & \multicolumn{5}{|c|}{2009} & \multirow{2}{*}{ Total } \\
\hline & & May & June & April & May & June & July & August & \\
\hline (1) Estuary of Bortala River & $44^{\circ} 52^{\prime} \mathrm{N}, 82^{\circ} 42^{\prime} \mathrm{E}$ & 7 & & & 1 & 1 & & & 9 \\
\hline (2) Silver Shoal & $44^{\circ} 50^{\prime} \mathrm{N}, 82^{\circ} 51^{\prime} \mathrm{E}$ & & 12 & 61 & 7 & 14 & & & 94 \\
\hline (3) Crab Pond & $44^{\circ} 48^{\prime} \mathrm{N}, 82^{\circ} 51^{\prime} \mathrm{E}$ & & & & 15 & 1 & & & 16 \\
\hline (4) Estuary of Jinghe River & $44^{\circ} 48^{\prime} \mathrm{N}, 82^{\circ} 55^{\prime} \mathrm{E}$ & & & & 5 & & 4 & & 9 \\
\hline (5) Aquaculture Farm & $44^{\circ} 47^{\prime} \mathrm{N}, 82^{\circ} 54^{\prime} \mathrm{E}$ & & & & 2 & & & 1 & 3 \\
\hline (6) Bazihu Lake, Alataw Pass & $45^{\circ} 09^{\prime} \mathrm{N}, 82^{\circ} 37^{\prime} \mathrm{E}$ & 2 & & 2 & 3 & 2 & $3+2$ (juvenile) & & 14 \\
\hline \multicolumn{2}{|c|}{ Total } & 9 & 12 & 63 & 33 & 18 & 9 & 1 & 145 \\
\hline
\end{tabular}

In mid May 2008, 2 and 7 Relict Gulls were detected at Alataw Pass and the estuary of the Bortala River respectively (Fig.1). Twelve gulls were counted at the Silver Shoal of southern Ebinur Lake on 16-17 June, and no gulls were recorded in subsequent observations in October 2008. At the Silver Shoal (from the estuaries of the Bortala River to the Jinghe River), 17 gulls were detected on 4 April 2009, and 61 gulls (1\% of the global population) between 25 and 26 April. On 18 May, 24 gulls were recorded on the shoal and ponds, and 3 gulls at the Bazihu Lake near Alataw Pass. According to their plumage and pairing, these gulls appeared to be breeding here. Ten to 18 gulls were counted on 23-24 June at these sites. We searched for their breeding ground in 2008 and 2009 but in vain. Two fledglings, which may have been local offspring, together with seven adults were found on 25-26 July 2009. The results of counting one gull in August and zero in September and October indicate that they had left Ebinur Lake in succession. The seasonal variation in gull population with one single peak (Fig. 3) obtained by survey around the lake in

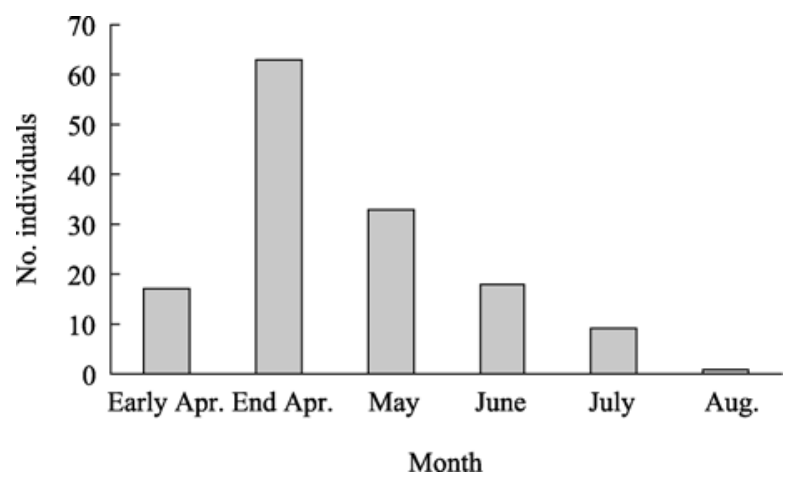

Fig. 3 Seasonal changes in Relict Gull numbers at the Ebinur Lake region during the period of April -August, 2009
2009, proved that the Relict Gulls were summer visitors within the study area.

\section{Discussions}

Generally, the Relict Gull is breeding on and around the Mongolian Highlands and at present has four isolated breeding populations (He et al., 2002). The first population is in Central Asia, around the Alakol Lake $\left(46^{\circ} 10^{\prime} \mathrm{N}, 81^{\circ} 50^{\prime} \mathrm{E}\right)$ and Balchas Lake in Kazakhstan. The second is in the Gobi Desert $\left(45^{\circ} 08^{\prime} \mathrm{N}, 101^{\circ} 27^{\prime} \mathrm{E}\right)$, scattered across almost the whole central and western Gobi of the People's Republic of Mongolia and Inner-Mongolia in China. The third population is in the Far-East, in the Chita Region of eastern Russia, northeast Mongolia and northeast China (e.g. the Torey Lake, $50^{\circ} 10^{\prime} \mathrm{N}, 115^{\circ} 30^{\prime} \mathrm{E}$ ), and, the fourth is on the Ordos Plateau $\left(39^{\circ} 48^{\prime} \mathrm{N}, 109^{\circ} 35^{\prime} \mathrm{E}\right)$. This is the largest breeding population in China (Zhang et al., 1993).

The Ebinur Lake is the largest inland salt lake in Xinjiang, covering an area of $1,200 \mathrm{~km}^{2}$ when full. The distance from the Alakol Lake in Kazakhstan through the Alataw Pass to the Ebinur Lake region is only $80 \mathrm{~km}$. Some data from Kazakhstan showed that the Relict Gull colony in the Alakol Lake was very unstable, with 1,200 pairs at most (Wassink and Oreel, 2007). So it is recommended that the gulls from both lakes should be considered as parts of the same 'Central Asia population' for the moment.

One juvenile Relict Gull ringed in the Alakol Lake $\left(46^{\circ} 42^{\prime} \mathrm{N}, 81^{\circ} 52^{\prime} \mathrm{E}\right)$ on 24 June 1977 was recovered in Yimen County $\left(24^{\circ} 36^{\prime} \mathrm{N}, 102^{\circ} 06^{\prime} \mathrm{E}\right)$, Yunnan Province in August 1977 (Zhang et al., 1997). In Northern Vietnam a juvenile gull with a ring was retrieved (Auezov, 1974). There was also some recovery infor- 
mation of banded birds from Turkey and Bulgaria (Gavrilov et al., 2000), which is about $4,000 \mathrm{~km}$ to the west of the known range. All these records have shown that the migration of the juvenile gulls inhered in a radiation form (He et al., 2002). But the migratory routes and over-wintering grounds of adult gulls are still unknown.

These observational studies allowed us the chance to confirm the taxonomy of the Relict Gull. It has long been considered that the hood shape of the gull is an uncertain taxonomic character, and possibly the result of hybridization with, or a variety or subspecies of the Mediterranean Gull (Larus melanocephalus), the Great Black-headed Gull (Larus ichthyaetus) or the Brown-headed Gull (Larus brunnicephalus) (Lönnberg, 1931; Vaurie, 1962; Zhang et al., 1994; del Hoyo et al., 1996; He et al., 1998; Wang et al., 2006). The Relict Gull was recognized as a separate species 40 years ago (Auezov, 1971). The Relict Gull in China belongs to (1) the First Category for Conservation of a Nationally Protected Wildlife Species (Law of Wildlife Protection in China, 1988), (2) the rare species list of Appendix I of the Convention on International Trade in Endangered Species of Wild Fauna and Flora (CITES), and (3) a species of Appendix I on the Convention on Migratory Species (MSC), in the publications of the Red List (IUCN, 2002), 'Threatened Birds of Asia' (BirdLife International, 2001). The gull has been named as a narrowly distributed and vulnerable species (VU) in the world.

Rose and Scott (1997) deduced from regional census that there were 10,000-12,000 individuals Relict Gulls in the world. Recently, many inland lakes have dried up because of drought in Asia, and the population of Relict Gulls has rapidly decreased to around 6,000 individuals at present. The colony in the Alakol Lake (part of the Central Asian population) has varied greatly in the years in which they have been studied. There were 30-1,200 pairs between 1969 and 1984, 11-305 pairs between 1985 and 1989 (Duff et al., 1991), but only a single gull was seen in May 1998 (Wassink et al., 2007). The Ebinur flocks should provide powerful evidence for the transference and survival status of the Central Asian colony. This area provides the westernmost breeding record in China. Comparatively, the Ordos colony in China was stable and possessed 2,887-3,594 nests between 1998 and
2001, which accounted for $50 \%-60 \%$ of the global population (He et al., 2002). As a semi-desert and desert species, it is understandable for the Relict Gull to exhibit a changeable population when inhabiting the small islets in salt lakes. However, acute climate changes and increasing human disturbance adversely affect the Gull's chances to recover its population.

The Ebinur Lake is an important staging point for migrating birds. Every fall 100,000-200,000 waterfowl pass through here. In the round-lake survey, more than 220 other species were recorded, including the Red-necked Grebe (Podiceps grisegena), Little Bittern (Ixobrychus minutus), Dalmatian Pelican (Pelecanus crispus), White-headed Duck (Oxyura leucocephala), Short-toed Eagle (Circaetus gallicus), Lesser Kestrel (Falco naumanni), Demoiselle Crane (Anthropoides virgo), Houbara (Chlamydotis macqueenii), Turnstone (Arenaria interpres), Little Gull (Larus minutus), Slender-billed Gull (Larus genei), Gull-billed Tern (Gelochelidon nilotica), Black Tern (Chlidonias niger) and Black-bellied Sandgrouse (Pterocles orientalis). Except for some raptors, natural enemies for waterfowls around the lake include wolves, stoats, weasels, mink (invasive species), badgers, wild cats and foxes.

In the past few years, human activities have greatly threatened the survival of the Relict Gull flock (including predation by wild animals). Such activities include contamination by industrial effluent, unreasonable tourism development, unplanned land clearing and crop cultivation, pumping water and salt mineral extraction, overgrazing, logging (illegal lumbering), intercepting the rivers for irrigation, digging herbal medicines, digging crab ponds, fishing for Brine Shrimp (for which there are no controlling regulations in the Ebinur National Reserve), picking up birds' eggs and poaching. Some of these may have come about or been made worse due to confused land use entitlements or regulations. One of the worst activities has been the abusive use of pesticides and herbicides, intended to exterminate pests and rodents, but resulting in killing almost all birds in oases, such that species from the sparrow to the crow and magpies are now extinct in parts of the countryside. These improper activities were partly due to some unreasonable decision-making by government or destructive resources utilization. The appearance of the Relict Gull and other birds in the Ebinur Lake is good news for 
the conservation of Xinjiang's Wetlands. Hopefully it will rouse people's attention again to the environmental problems in Xinjiang. Recently the Global Environment Facility and Asian Development Bank have committed to help restore the eco-environment of the Ebinur Lake, and we expect the deteriorating survival environments of wildlife would start to be improved.

\section{Acknowledgements}

The research is supported by Science Supporting Project of National Ministry of Science and Technology (2008BAC39B04), National Natural Science Foundation of

\section{References}

Auezov E M. Taxonomic evaluation and systematic status of Larus relictus. Zoologischeskii Zhurnal, 1971, 50: 235-242.

Auezov E M. North Vietnam, a new place for finding Larus relictus. Zoologischeskii Zhurnal, 1974, 53: 139.

BirdLife International. Threatened Birds of Asia: the BirdLife International Red Data Book. Cambridge: BirdLife International, 2001. 1478-1487.

Chen C D, Yuan G Y, Zhou X J, et al. The Environment Problem and Countermeasures for Shrinking Lake Ebinur. Beijing: Science Press, 1989. 187-198.

del Hoyo J, Elliott A, Sargatal J. Handbook of the Birds of the World. Barcelona: Lynx Edicions, 1996. 572-618.

Duff D G, Bakewell D N, Williams M D. The relict gull Larus relictus in China and elsewhere. Forktail, 1991, 6: 43-65.

Gavrilov E I, Gavrilov A E. Possible ringing recoveries of relict gull in Bulgaria and Turkey. Dutch Birding, 2000, 22: 219-221.

He F Q, Zhang Y S. About some uncertainty of the distribution and taxonomy of Larus brunnicephalus and Larus relictus. Acta Zootaxonomica Sinica, 1998, 23(1): 105-111.

He F Q, Melville D, Xing X J, et al. A review on studies of the relict gull Larus relictus. Chinese Journal of Zoology, 2002, 37(3): 65-70.

Lönnberg E. A remarkable gull from the Gobi Desert. Arkiv Fur Zoology, $1931,23 b(2): 1-5$.
China (30470262, 30970340). This survey around Ebinur Lake was sponsored and supported by Bortalar Forest Bureau, the manager from Department of Ebinur Lake National Reserve, Forest Conservation Center, Chinese Academy of Sciences, Xinjiang Institute of Geography and Ecology, an elaborate arrangement with Global Environment Facility (GEF) and great assistance from every field station in the reserve. Sincere thanks go to all participants especially to XinMin ZHANG, Reheman Amanjiang, FenQi HE, Batenasheng, Yaerfan, HaiLin SU, QuDan CAI, Dilixiati Yasen, Balabayi, DeHu WANG, Peng DING, XiaoShou YAN, WenHua LI, Tony Whitten, Malcolm Douglas, GuanHua QIU, Paul Holt, JianJian LU, Judith Schleicher, ZhiGang JIANG, NaiFa LIU, and HaiGen XU.

Ma M, Lu J J. Wetland and the waterfowl in Xinjiang. Chinese Biodiversity, 1997, 5 (Suppl.): 10-14.

Ma M. Important bird areas (IBAs) and globally threatened birds in Xinjiang, China. Arid Zone Research, 1999, 16(3): 19-22.

Ma M. A checklist of the birds in Xinjiang, China. Arid Zone Research, 2001, 18 (Suppl.): 28-30.

Rose P M, Scott D A. Waterfowl Population Estimates. 2nd ed. Wageningen: Wetland International Publication. 1997. 44.

Vaurie C. The status of Larus relictus and of other hooded gulls from central Asia. Auk, 1962, 79: 303-309.

Wang Q S, Ma M, Gao Y R. Fauna Sinica. Aves, Gruiformes, Charadriiformes and Lariformes, Vol.5. Beijing: Science Press, 2006. 469-473.

Wassink A, Oreel G J. The Birds of Kazakhstan. Texel: De Cocksdorp. 2007. 107-111.

Yan C W, Zhu G Y, Chen S H. The Laridae and the Sternidae in China. Nantou: National Fenghuanggu Bird Garden, 2006. 81-85.

Zhang Y S, Ding W N, Chen R B, et al. Breeding ecology of relict gull in Ordos of Inner Mongolia Area. Acta Zoological Sinica, 1993, 39(2): 154-159.

Zhang Y S, He F Q. On the taxonomic status of the relict gull. Acta Zootaxonomica Sinica, 1994, 19(3): 379-382.

Zhang F Y, Yang R L. Bird Migration Research in China. Beijing: Chinese Forestry Publishing House, 1997. 124-125. 